\title{
USING CHEMICAL MODELS FOR DEVELOPING NATURAL SCIENCE COMPETENCES IN TEACHING CHEMISTRY: FROM PUPILS AS MODEL ASSEMBLERS TO PUPILS AS CREATORS OF SELF-MADE MODELS
}

\author{
Darinka Sikošek, Mateja Žuželj \\ University of Maribor, Maribor, Slovenia \\ E-mail: darinka.sikosek@uni-mb.si, mateja.zuzelj@gmail.com
}

\begin{abstract}
Chemical models are indispensable tool in chemistry class and enable secondary school pupils to develop complex thought processes and spatial concepts, both of which are necessary to improve their understanding of chemical concepts.

In this research, special emphasis is given to complex competencies not only their acquisition, but rather how pupils develop them. For this purpose, a learning strategy has been developed, called learning by self-generating chemical models. Pupils learn individually on their own models, which are made from easily accessible, low-cost materials.

The impact of workable models was investigated (assembly of commercial models and production of selfmade models) on the (1) learning success using simple molecule shapes and (2) the degree of competence development which realized through the implemented activities. The study involved first-year secondary school-pupils, defined as self-creators of paper-and-wire models (experimental group) and assemblers of commercial models (called the control group). The appearance of the molecules being studied took the form of geometric shapes and structures, which pupils present by making of ball-, called wire-models from plasticine and wire or paper created, called paper models.

Based on the results of statistical processing of the data, we found that self-creation of models (as an innovative approach) leads to better understanding and to subsequently sustained knowledge for the pupil. It should also be noted that pupils who were self-generators in comparisons to those who merely assembled the models, generally developed many complex skills in the areas of problem solving, practical competence, mathematical competence and critical thinking skills. The knowledge so acquired was also better understood.
\end{abstract}

Key words: chemical models, competencies, self-made models, teaching and learning by models.

\section{Introduction}

In a scientific model, objects in the real world are represented by other objects, mathematical descriptions, or computer programs. Every model is like the real thing in some ways and different from the real thing in some ways (Barber, 2011). As Bent (1984, p. 774) said, to be useful, a model must be wrong, in some respects, else it would be the thing itself. Models have function as a bridge between scientific theory and the world-as-experienced ('reality') (Gilbert, 2004, p. 116).

On the other hand chemical models as representations to the human eye of invisible structures make possible the rapid and clear acquisition of abstract concepts. Therefore, they 
Darinka SIKOŠEK, Mateja ŽUŽELJ. Using Chemical Models for Developing Natural Science Competences in Teaching Chemistry: From Pupils as Model Assemblers to Pupils as Creators of Self-Made Models

OF EDUC

IN THE $21^{\text {st }}$ CENTURY Volume 53,2013

are of great importance for the development of formal thinking in the transition from a concrete to a formal level of intellectual development, helping to develop logical thinking and reasoning (Siko ek, 2006, p. 25). Of course, this is only possible when pupils are actively engaged in the creation (manufacture), use and selection of models for molecular description, explanation, prediction and control of chemical phenomena (Ornek, 2008, p. 44).

The authors Ferk-Savec and Dolničar (2008) have observed that many studies confirm that pupils' integration of molecular models into the learning process improves their understanding of the particle-based nature of the substance but also increases their intellectual abilities. Various studies suggest that the achievements of pupils in chemistry depend on their capacity for spatial conception, which can be greatly improved using different types of models (Ferk -Savec et al. 2006, p. 382). For optimal learning using the chemical models, it is recommended to combine different types of molecular models and to ensure that they are accessible to all pupils in the class, which represents a large financial cost (Vrtačnik et al., 2003, p. 10). For visualization skills, the method presentation of models is very important: pupils are more successful in solving tasks where the molecules are represented by three-dimensional photo or a ball model presented as a computer model, compared to more abstract schematic or symbolic format for molecules (Ferk-Savec, 2000).

Teacher demonstration of previously assembled models and pupils' assembly of models are the most commonly used techniques with models. Devetak et al. (2010) note that it is much better (for a better understanding of the issues) to allow assembly from designs by pupils. We certainly agree with this because the pupil-assemblers of models develop specific competencies and participate actively in class. However, we believe that pupils, even those with no problems, do not fully understand the assembly models. In our view, pupils assemble the chemical models without thinking or knowing what the grooves on the balls are and what is the meaning of the different colored balls of different sizes and variable lengths that form the links in these models. There have arisen several misconceptions about the many models that have subsequently been very difficult to eliminate, or at least mitigate.

\section{Research Problem}

Based on the principles of learning activity, above all from the intellectual perspective of view (consistently taken into account), it was necessary to develop a more active form of model manipulation, called self-generation: pupils themselves make their own models using easily accessible, affordable material. Similar models made by teachers or pupils have already made in 1928 by Wade, in 1931 by Scott and in 1932 by Pouleur, and also later in 1960 by Sanderson. On the other hand self-made models are interesting and instructive for pupils and also not too expensive (Hehre and Shusterman, 2000, p. 8).

Figures 1 and 2 show examples of self-made wire and paper models created by pupils who participated in this empirical research.

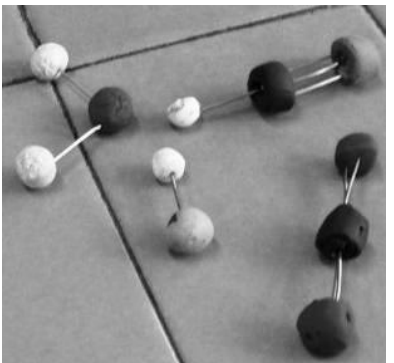

Figure 1: Self-made wire model (Žuželj, 2012).

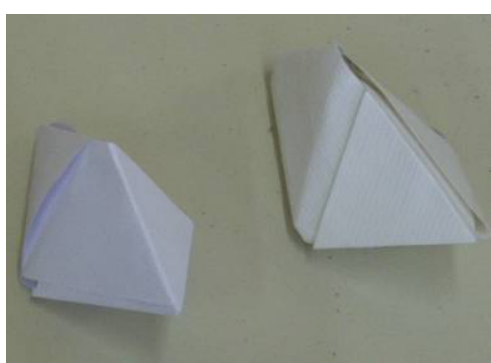

Figure 2: Self-made paper model (Žuželj, 2012). 
Darinka SIKOŠEK, Mateja ŽUŽELJ. Using Chemical Models for Developing Natural Science Competences in Teaching Chemistry: From Pupils as Model Assemblers to Pupils as Creators of Self-Made Models

In the case of self-generation of models, it is important to encourage pupils towards an independent search for and selection of materials, as well as in techniques for creating the selfmade models (Kenney, 1992). Thus, the planning and "manufacture" of self-made models is left to their critical judgment (Meža, 2004, p. 34). If pupils learn to consider the diversity of different materials and what may appear to them as well as the right angles, all the principles and information, then they need to understand the self-creation process even better then is necessary for commercial models, which have all been pre-defined (Kornhauser, 1972, p. 21). It is also important to give them a free hand to find all the information needed for proper model-making (MacKay, 2012). Thus, they are able to develop many competences, especially the ability to (a) gather information, (b) analyze and organize information, (c) make interpretations, (d) learn and solve problems, (d) think critically and (e) learn to work independently.

\section{Research Focus}

By implementing the learning unit (i.e., the didactic unit "The Form of Simple Molecules"), investigated the effectiveness of teaching the use of self-made as opposed to commercial models was investigated comparatively. In addition to focusing on teaching and learning using self-made models, was also examined the impact of pupils self-awareness, what knowledge and competences were developed during these activities. The focus of the research was not merely on a method of construction or self-generation and or for identifying the strengths and limitations of the models and verifying the effectiveness of innovative teaching strategies, but above all we focused on the learning of chemistry content while self-creating the models and developing a number of complex competences.

It is therefore possible to ask whether the role of self-made models could be upgraded by using existing commercial models already in use for teaching and learning chemistry, and how such learning could provide a better understanding of chemistry content and contribute to the development of the complex competencies required in modern society.

According to the hypothesis, the pupils as model self-generators will gain deeper knowledge of and better development in some generic and science competences (the ability to solve problems, critical thinking skills, learning competence, visualization, mathematical, practical and creative competences) than their peers who function merely as assemblers of models.

\section{Research Methodology}

\section{Sample of Research}

Regarding to the low class enrollment of pupils and implementing specific situation at the participating schools were willing to participate in the research, only 40 in the first year and 6 pupils in the third year of two middle schools were sampled; of these, 19 came from a chemical technician program, and 27 were technical high school program pupils.

The research sample (performing a comparative analysis) was divided into two groups: the control and experimental group. The pupils in the control group (CG in advance) were limited to assembling commercial models ( 25 pupils or $54.3 \%$ ), while the experimental group (EG in advance) worked at constructing their chemical models. This research was conducted in the school year 2011/2012.

\section{Instrument and Procedures}

Two measurement instruments, namely s.c. control test and a questionnaire were used for purposes of this search. The first one consists of 4 tasks of different types (complementary, free response), and these tasks check in particular the shape and bonding angles of molecules. Thus, for example Task 1 reviews the development of spatial concepts, while Task 4 deals with the ability of pupils to use newly acquired knowledge. 
Darinka SIKOŠEK, Mateja ŽUŽELJ. Using Chemical Models for Developing Natural Science Competences in Teaching Chemistry: From Pupils as Model Assemblers to Pupils as Creators of Self-Made Models

OF EDUCA

IN THE $21^{\text {st }}$ CENTURY Volume 53, 2013

The specific aims of the investigation are for pupils' to (a) know and identify the shapes of molecules and their properties, (b) infer the polarity of the molecule from its shape, (c) understand the impact of bonding and non-bonding electronic lone pairs upon the shapes of molecules, and (d) visualize the crossing between different chemical records (conversion from image to symbolic notation).

Pupils' own views on the competencies that they acquire and develop as assemblers or as creators of self-made models, were obtained using a questionnaire. Pupils responded to questions with a numerical value (on a scale of 1 to 5 ), with a 1 »zero or almost zero« and 5 »fully«, and were given 30 minutes to complete control the test and 15 minutes for the questionnaire.

The course of this research was broken into several steps: (1) verifying the pre-knowledge of pupils; (2) the implementation of a 90-minute activity: pupils' assembling (in control groups) and pupils' self-generating models (in experimental groups); (3) checking the quality of new knowledge gained; (4) testing (after a three-week interval) the sustainability of pupils' knowledge thus acquired, using the previously presented instruments for didactic analysis.

\section{Data Analysis}

The collected data were analyzed with SPSS Statistics $19^{\text {th }}$. These are presented in tabular and graphic form, where the absolute $\left(\mathrm{N}_{\mathrm{A}}\right)$ and relative frequency $\left([\%]_{\mathrm{A}}\right)$ responses are calculated. Analysis of efficiency at solving the test tasks is mainly derived from the arithmetic mean.

\section{Results of Research}

The first part of the results of this study, relating to the success of teaching and pupils' ability to use their newly acquired knowledge, was stated by analyzing the results obtained with the control test. A key emphasis of the second part of these results is focused on the competences acquired and developed by pupils either assembling or self-generating chemical models.

\section{Achievement of Pupils on the Control Test (Three Weeks After Performed Activities)}

Figure 1 and 2 present the achievement of pupils in the control test:

(1) The average values of the results obtained in Tasks $1-4$ and the total test (result on the graph with the number 5) in relation to different teaching strategy - assembling (control group) and individual designing (experimental group) of models (see Figure 1);

(2) The average values of the results achieved on Tasks 1-4 and tested together with different types of models (commercial, paper, wire), see Figure 2).

The results in Graph 1 show that the pupils who assembled pre-fabricated models as the control group achieved the minimum score on the test (on average 45.36\%). Pupils who were exposed during the learning only to self-generation of models achieved results that were on average $6.00 \%$ better result, namely $51.43 \%$ (this is the number 5 on the $\mathrm{x}$-axis, i.e. the test items on the graphs). Pupils as model generators better solved all individual, separately controlled tasks except Task 2. The biggest difference in performance between individual pupils' groups occurred on the task 3 (EG was in $15.65 \%$ more successful), which verified the content objective realization in teaching this topic, and Task 4 , where the difference between the two groups was as high as $19.62 \%$. 
PROBLEMS

OF EDUCATION

IN THE $21^{\text {st }}$ CENTURY

Volume 53, 2013

93

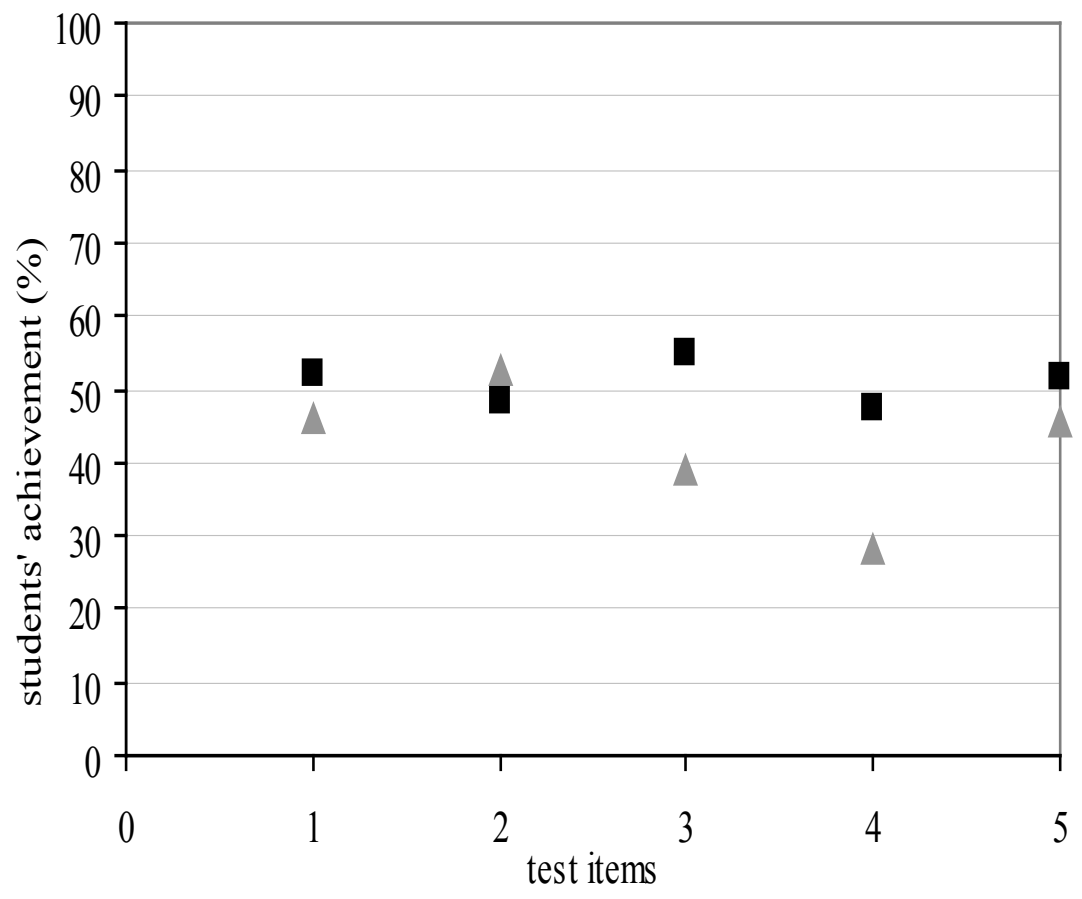

Figure 1: Pupils' test achievements (type of group).

Task 1 of the control test examined the ability of pupils to recognize the forms for drawing two-dimensional models of molecules, as well as a record of their connecting angles. Success at solving this task acted as a quality assessment for developing spatial concepts when working with models. We expected that pupils with a higher level of development of spatial performance (conception) would find it easy to identify the three-dimensional shape of two-dimensional image models. Improvement in the level of development of competences for $»$ performance space « is also reflected in the results of Figure 1, where self-generators of models achieved an average of almost $6.00 \%$ better results than the assemblers of commercial chemical models. Even larger differences are evident in Figure 2, which presents the difference in the development of spatial performance (conception) of the kind of shaped model. In the development of spatial performance (conception), the self-generators of paper models also show greater success; their results were almost $11.00 \%$ better than those of the wire models self-makers as well as those of the assemblers of commercial chemical models. Among those who generated wire models and the assemblers of commercial models, there were no differences in their achievements- which is surprising.

Similar results are also characteristic of pre-fabricated commercial and self-made models of different types (paper, wire), as seen in Figure 2. The self-generators of both types of models (paper and wire) were better at solving the control test than the assemblers of commercial models. Overall, the most successful are those who made their own paper models. They were distinguished from the assemblers of models by $7.00 \%$ and even from those who made their own wire models by $2.00 \%$. Differences in levels of success between the wire and paper model self-generators occurred only on Task 1 of the control test to a great extent, where the paper model self-generators dominated by nearly $11 \%$. The worst outcome for all tasks (with the exception of Task 2 with the highest score) involved commercial model assemblers. The model assemblers were less successful in the last two tasks, where they reached an average of $39.11 \%$ and $28.00 \%$; this is of more than $12 \%$ and $16.44 \%$ less than the models self-generators. 
Darinka SIKOŠEK, Mateja ŽUŽELJ. Using Chemical Models for Developing Natural Science Competences in Teaching Chemistry: From Pupils as Model Assemblers to Pupils as Creators of Self-Made Models

OF EDUCATION

IN THE $21^{\text {st }}$ CENTURY

Volume 53, 2013

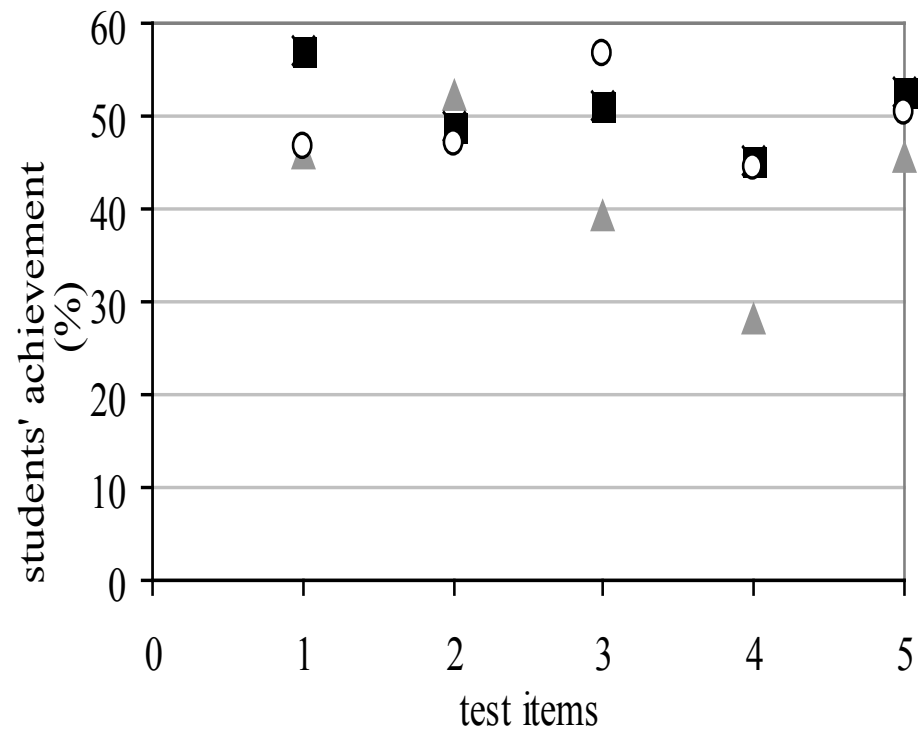

Figure 2: Pupils' test achievements (type of model).

Evaluation of Pupils on Developing and Acquiring Skills

Table 1. Categorized pupils' responses to the questions concerning the development of their own competencies during the activities.

\begin{tabular}{lcccccccccc}
\hline & \multicolumn{3}{c}{ Group } & \multicolumn{5}{c}{ Model } \\
\cline { 2 - 11 } Competences & $\begin{array}{c}\text { Control } \\
(\mathrm{N}=25)\end{array}$ & $\begin{array}{c}\text { Experimental } \\
(\mathrm{N}=21)\end{array}$ & $\begin{array}{c}\text { Commercial } \\
(\mathrm{N}=25)\end{array}$ & $\begin{array}{c}\text { Paper } \\
(\mathrm{N}=10)\end{array}$ & $\begin{array}{c}\text { Wire } \\
(\mathrm{N}=9)\end{array}$ \\
\cline { 2 - 12 } & $\mathrm{N}_{\mathrm{A}}$ & {$[\%]_{\mathrm{A}}$} & $\mathrm{N}_{\mathrm{A}}$ & {$[\%]_{\mathrm{A}}$} & $\mathrm{N}_{\mathrm{A}}$ & {$[\%]_{\mathrm{A}}$} & $\mathrm{N}_{\mathrm{A}}$ & {$[\%]_{\mathrm{A}}$} & $\mathrm{N}_{\mathrm{A}}$ & {$[\%]_{\mathrm{A}}$} \\
\hline Problem solving ability & 9 & 40.9 & 15 & 79.0 & 9 & 40.9 & 8 & 80.0 & 6 & 75.0 \\
Critical thinking skills & 13 & 59.1 & 16 & 84.2 & 13 & 59.1 & 8 & 80.0 & 7 & 87.5 \\
Learning to learn & 12 & 54.6 & 14 & 73.7 & 12 & 54.6 & 8 & 80.0 & 6 & 75.0 \\
Visualization & 13 & 54.2 & 14 & 70.0 & 13 & 54.2 & 8 & 80.0 & 5 & 55.5 \\
Mathematical competence & 11 & 45.8 & 15 & 75.0 & 11 & 45.8 & 9 & 90.0 & 5 & 55.5 \\
Practical competence & 8 & 33.4 & 14 & 70.0 & 8 & 33.4 & 8 & 80.0 & 5 & 55.5 \\
Creative competence & 11 & 45.9 & 14 & 70.0 & 11 & 45.9 & 8 & 80.0 & 5 & 55.5 \\
Motivation & 7 & 29.2 & 12 & 60.0 & 7 & 29.2 & 7 & 70.0 & 4 & 44.4 \\
\hline
\end{tabular}

$\mathrm{N}=$ number of pupils; $\mathrm{N}_{\mathrm{A}}=$ number of pupils who responded that this competency had developed to a level of "rather" or "quite"; [\%] $]_{\mathrm{A}}=$ percentage of pupils who have to develop this competency "quite" or "completely" (Note: two pupils did not evaluate their mark for development of all competencies, so percentages are calculated on the number of pupils who responded to each question).

Note: The values in the control group and the commercial model in the table are the same as the pupils of the control group (CG) composed of only the commercial models, while the experimental group (EG) pupils had to create two types of models: paper and wire models. The number of pupils in EG and the total of participants in the self-generation of both types of models varies because two pupil did not identify the type of model they had produced when they completed the questionnaire. 
Table 1 presents the evaluation of pupils in terms of the extent to which they in their activities (assembling or self-generating the chemical models) acquire and develop generic and natural science competences. Answers represent only those who felt that the activities implemented did fairly or fully develop these competences.

The level of competences' development, was again controlled according to the research group (CG and EG) and model type (commercial, paper or wire). As we can see from Table 1, all well studied competences are more fully developed by those who made their own models, the paper self-generators. The biggest gap in the development of generic and natural science competences in the research group occurred for the competence in the ability to solve problems and practical competence. These competences are developed $38.1 \%$ and $36.6 \%$ more by those who made their own models than the model assemblers.

Of course, members of EG developed their mathematical competence and critical thinking skills by about one quarter in the direction of being more creative. The least difference in the valuation of development in these competences occurs in the competences "learning to learn and visualization", where $19.1 \%$ and $15.8 \%$ of the models-makers estimated that these two were well developed by them.

Table 1 shows the differences in the level of development of individual science and generic competences in the assembly or manufacture of different types of models. Differences are also evident in the level of development of individual science and generic competences in the assembly or self-generator of the different types of models. The results show that both generic competences (except critical thinking skills) as well as natural science competences were developed among most of the paper models "manufacturers", since at least $80 \%$ of these significantly developed each of these competences. It is also evident that minor deviations occur in the rate of development of these competences between paper model and wire model makers, similar to those between the assemblers of commercial models and pupils who made their own. Concerning the development of the first three competences (problem-solving ability, critical thinking skills, learning to learn), there are small differences between the paper- and wire models creators. Major differences (about 24.5\%) occur in developing the practical and creative competences. The largest difference (about $34.5 \%$ ) is reflected in the development of the mathematical competence, which was fully developed by almost all who made their own paper models; as many as $90 \%$ of them estimated that this competence was developed to the greatest extent. On the other hand, there are significant differences (between 20 and 34\%) in the development of the first three competences between the assemblers of commercial models and the creators of models. For both scientific competences (mathematical and practical) and artistic (creative) competences, there can be seen much larger differences (Table 1) between the assemblers of commercial and the manufacturers of paper models (from 34.1 to $46.6 \%$ ), while this difference is much smaller (from 9.6 to $22.1 \%$ ) between commercial model assemblers and wire model self-manufacturers.

In developing the visualization competence, small differences can be highlighted in the assessment of commercial models assemblers and wire model self-creators; figures are higher for the paper model self- creators (around 25\% of these are estimated to have this competency fully developed).

From Table 1 we can see differences in pupil motivation: $70.0 \%$ of the paper model creators were very motivated, as compared to $44.4 \%$ of the wire model creators and just $29.2 \%$ of the commercial model assemblers. Therefore, it is not surprising that $30.8 \%$ more at those who made their own models were more motivated than the commercial model assemblers.

\section{Discussion}

The research results indicate the correctness of the defined assumption about the higher performance of model self-generators in designing and developing deeper self-knowledge, as well as in acquiring a number of generic and natural science competences. Those who made 
Darinka SIKOŠEK, Mateja ŽUŽELJ. Using Chemical Models for Developing Natural Science Competences in Teaching Chemistry: From Pupils as Model Assemblers to Pupils as Creators of Self-Made Models

OF EDU

PROBLEMS

IN THE $21^{\text {st }}$ CENTURY

Volume 53, 2013

their own models were $6 \%$ more successful at solving the control test than were those pupils who only assembled commercial models. This finding is also supported by the success achieved on the control test, where the paper model self-creators were also the most successful and the assemblers of pre-fabricated models the least successful.

In any case, these results are not surprising, since the pupils as designers of their own models actively participated both mentally and physically in the construction of their own knowledge; they realized a new way of learning and at the same time also enjoyed the process. It is assumed that their major motivation for the implementation of the planned learning activities was mainly due to the choice of this innovative approach to teaching them a previously unknown learning strategy. The wire models (similar to ball commercial models) made the pupils themselves from readily available materials proved to be very motivational. The same is true for making paper models, which otherwise are not made in the classroom.

Very similar conclusions were found from further analysis of the performance of individual tasks on a control test: for all tasks (except the second one), the pupils in the experimental group achieved a better average result than the control group. The most prominent is the finding that pupils in the experimental group used their newly acquired knowledge $20.00 \%$ effectively (Task 4). Undoubtedly, the knowledge gained from making your own chemical models was better understood and therefore also much more efficiently used in new situations.

In terms of acquiring and developing these generic and natural science competences, we can confirm that more than $70.0 \%$ of pupils who created their own models developed to the fullest extent all the study competences, while among the assemblers the figure was only $33.4 \%$. In particular, we can highlight the evaluation of the paper model "manufacturers", including as many as $80.0 \%$ of them who judged that all the competences had been developed by a assigning rating of »very« or »completely.« Pupils participating in the research primarily develop the generic competency, "critical thinking skills", when they evaluate during their self-learning the strengths and weaknesses of both pre-fabricated commercial models as well as self-produced chemistry models. According to the participants' evaluation, they developed practical competence the least, but this was true to a lesser extent for the assemblers of commercial models, while this competence was largely developed in $80.0 \%$ of all paper model self-generators. This result is a little surprising, since during the assembly of commercial chemical models, manual skills are highly developed.

The "manufacture" of chemical models has also been associated favorably with the development of mathematical competence, because it was necessary to take into account the mathematical laws of geometric bodies, to measure the length of links, the size of connection angles, and to convert and evaluate current units and the like. Similar conclusions for the mathematical and practical competences can also be highlighted for the creative competence. In realizing the competence "learning to learn", the participants used these activities to recognize what is apparent from the results collected.

Among commercial model assemblers and model creators there is no significant difference in achievement, either on the control test or on the evaluation of the development of visualization. This conclusion is not surprising, since the paper model creators by making the geometric shapes and structures as actual forms of the given molecules, gained deeper insight into the geometry of the shapes of molecules.

One should be aware of the limitations of a statistically small sample size and the resulting limited ability to generalize the results; however, they are useful for further research to develop this approach, since the need to "manufacture" models (especially in chemistry) is becoming a challenge to the methodology of teaching and learning for future generations.

The need for self-made models is now becoming more evident, not only from the financial point of view (e.g., the cost of purchasing more and different types of models), but we must also take into account the principle of greater pupil activity in acquiring their own knowledge. Teachers are not and should not be mere transmitters of knowledge to their pupils; as teachers, we must teach pupils how to teach themselves, how to meet the challenge of various situations and how to extend their personal development into broader areas of competence. 


\section{Conclusions}

The central research aim of this study is to apply a teaching-learning approach with chemical models, which could lead to a better understanding of the chemistry content and to the acquisition as well as development of complex competences required by the active individual of modern society. The basic characteristic of this approach is the strategy of letting pupils makes their own models. Using these models, pupils construct their knowledge in an innovative and active manner and come to a deeper understanding of chemical concepts as well as developing a number of complex competences. Of course, pupils' self-made models can and should be are understood as aesthetic products on the border between art and science, since their creation is a creative act, which requires pupils' intense, both mental and emotional creative engagement.

The approach using self-made models shows to highlight the following key findings:

(1) time-wise, it very demanding in teacher training as well as during the introduction to pupils; (2) considering the principles of gradualism and systematic learning, the creation of models must take place step by step, as follows: (a) choice of the molecules for which models will be built; (b) selection of the kinds of models and materials which would be used; (c) drawing structural formulas of selected molecules; (d) searching all data necessary for proper model making (size of atoms of elements, radius length, shape of molecules, etc.), (d) planned making of molecules models; (e) evaluation of the completed chemical models ; (f) use of these models for problem solving, learning, etc.; (3) learning by self-made chemical models proved to be useful and encouraging in terms of realizing both the principle of activity as well as the principle of individualization, since every pupil in the research sample was included in the construction of their own knowledge and in developing so many generic as well as key and subjectspecific competences; (4) it was confirmed that pupils had pronounced problems with clarity, and consequently the spatial representations and visualization of three-dimensional forms which can be used in self-made models greatly improved, if not partly eliminated the problem; (5) role models in teaching chemistry may be the popular commercial chemical models significantly_enhanced with the implementation of an innovative approach, the so-called models self-making. Of course, the strategy of effective transfer of this approach to the teaching and learning process requires strict consideration of the principles of gradual and systematic action.

From all the research results it can be claimed that pupils who make their own models are at a great advantage regarding the acquisition of deeper knowledge and understanding of chemical concepts, as well as in the development of many competences. Undeniably, we convinced ourselves that many pupils have difficulties in converting two-dimensional shapes to three-dimensional models.

Let us not forget that pupils, who are well prepared for the increasing complexity of life and work in the 21st century, can be distinguished from those who are not by mastery the following three competencies: (1) Creativity\&Innovation, (2) Critical thinking\&Problem solving, (3) Communication \& Cooperation. In fact, these are precisely the competences that are the most engaged by the chemical model self-generators, and as such, they are also the most developed.

\section{Acknowledgements}

The authors would like to sincerely thank all the chemistry teachers and their pupils who participated in this research.

\section{References}

Barber, J. (2011). Teaching about how scientists use models with planetary scientist. University of California, Delta education. Retrieved 12/04/2012 from http://www.deltaeducation.com/downloads/ samples_seeds/1356095_SG_PM_Planetary_Scientist.pdf. 
Darinka SIKOŠEK, Mateja ŽUŽELJ. Using Chemical Models for Developing Natural Science Competences in Teaching Chemistry: From Pupils as Model Assemblers to Pupils as Creators of Self-Made Models

PROBLEMS

OF EDUCATION

IN THE $21^{\text {st }}$ CENTURY Volume 53, 2013

Bent, A., H. (1984). Uses (and abuses) of models in teaching chemistry. Journal of Chemical Education, $61(9), 774-777$.

Devetak, I., Hajzeri, M., Glažar, A., S., \& Vogrinec, J. (2010). The influence of Different Models on 15-years old Students' Understanding of the Solid State of Matter. Acta Chimica Slovenica, 57, 904-511.

Ferk-Savec, V. (2000). The impact of different molecular structure representations on the process of perception, rotation and reflection. Master's Thesis, Ljubljana.

Ferk-Savec, V., Vrtačnik, M., Gilbert, K., J. \& Peklaj, C. (2006). In-Service and Pre-Service Teachers' Opinion on the Use of Models in Teaching Chemistry. Acta Chimica Slovenica, 53, 381-390.

Ferk-Savec, V., \& Dolničar, D. (2008). Uporaba molekulskih modelov pri poučevanju in učenju kemije. Retrieved 19/05/2011 from, http://www.kii.ntf.uni-lj.si/keminfo/grad/uporaba_modelov/Kazalo. htm.

Gilbert, J. K. (2004). Models and modelling: Routes to more authentic science education. International Journal of Science and Mathematics Education, 2, 115-130.

Hehre, J. W., \& Shusterman, J. A. (2000). Molecular modeling in undergraduate chemistry. Irvine: Wavefunction, Inc. [electronic version http:/www.wavefun.com/support/MMUndEd.pdf].

Kenney, T. (1992). Molecular models in general chemistry. Journal of Chemical Education, 69, (1), 67.

Kornhauser, A. (1972). Konstrukcija in uporaba atomskih in molekularnih modelov pri pouku. Vzgoja in izobraževanje, 3 (1-2), 18-25.

MacKay, B. (2012). Teaching with models. Retrieved 12/04/2012 from http://serc.carleton.edu/introgeo/ models/index.html.

Meža, Ž. T. (2004). Drugačni modeli - drugačen pouk. Kemija v šoli, 16 (3), 34-35.

Ornek, F. (2008). Models in science education: Applications of models in learning and teaching science. International Journal of Environmental \& Science Education, 3 (2), 35-45.

Pouleur, L. A. (1932). Atomic and molecular structure as a visual aid in the teaching of chemistry. Journal of Chemical Education, 9 (2), 301-316.

Sanderson, R. T. (1960). Atomic models in teaching chemistry. Journal of Chemical Education, 37 (6), E307-310.

Scott, E. C. (1931). Atomic models for use in teaching inorganic chemistry. Journal of Chemical Education, 8 (9), 1845-1851.

Siko ek, D. (2006). Predmet: Didaktika kemije I: snopič predavalnih izročkov: univerzitetni pedagoški dvopredmetni program »Kemija in... «. Maribor: Univerza v Mariboru, Fakulteta za naravoslovje in matematiko.

Vrtačnik, M., Ferk, S. V., Fir, M., Dolničar, D., Renič, V., Potisk, B., \& Pozderec, N. (2003). Dinamična vizualizacija naravoslovnih pojmov s poskusi in modeli: priročnik za učitelje. Ljubljana: Univerza v Ljubljani, Naravoslovnotehniška fakulteta.

Wade, W. I. (1928). Construction and use of models in chemistry. Journal of Chemical Education, 5 (2), 193-196.

Žuželj, M. (2012). Delo z modeli pri pouku kemije z uporabo geometrijskega znanja (Teaching and Learning Chemistry by Using Models and Geometric Knowledge) : Graduation Thesis, Maribor: Univerza v Mariboru, Fakulteta za naravoslovje in matematiko, Oddelek za kemijo - Katedra za kemijsko izobraževanje.

Advised by Todar Lakhvich, Belarusian State M. Tank Pedagogical University, Republic of Belarus

Received: January 30, 2013

Accepted: March 26, 2013

\begin{tabular}{|ll|}
\hline \multirow{2}{*}{ Darinka Sikošek } & PhD., Assistant Professor at Faculty of Natural Science and Mathematics, University of \\
& Maribor, Koro ka160, Maribor, Slovenia. \\
& E-mail: darinka.sikosek@uni-mb.si \\
& Website: http://www.fnm.uni-mb.si \\
\hline \multirow{3}{*}{ Mateja Žuželj } & University Graduate (Teacher of Chemistry and Mathematics), University of Maribor, \\
& Koroška 160, Maribor, Slovenia. \\
& E-mail: mateja.zuzelj@gmail.com \\
& Website: http://www.fnm.uni-mb.si
\end{tabular}

